\title{
Animal Waste Management Become Compost and Straw Fermentation Technology in Sumberejo Mranggen Demak Central Java
}

\author{
E. Fuskhah ${ }^{1 *)}$ and S. Sumarsih ${ }^{1}$ \\ ${ }^{1}$ Faculty of Animal Sciences and Agriculture, Diponegoro University, Tembalang Campus, Semarang \\ 50275
}

\begin{abstract}
The problem experienced by farmer groups in Sumberejo Village, Mranggen Subdistrict, Demak Regency was that it had not managed well the manure that exists to mount beside the cage, the difficulty of providing forage / grass especially in the dry season and the length of time counting grass for livestock, so farmers often provide just the grass or straw he got. Even if the grass was enumerated before being given livestock, it would increase the digestibility so that it would add value to the livestock. The solutions offered were education and counseling for the processing of livestock waste into compost, efforts to utilize rice and corn straw with fermentation technology, and efforts to improve cattle feed by using grass chopping tools.
\end{abstract}

Keywords: Compost, Fermented rice straw

\begin{abstract}
Abstrak. Permasalahan yang dialami kelompok tani di Desa Sumberejo Kecamatan Mranggen Kabupaten Demak adalah belum terkelolanya dengan baik kotoran ternak yang ada sampai menggunung disamping kandang, sulitnya penyediaan hijauan/rumput khususnya pada musim kemarau dan lamanya waktu mencacah rumput untuk diberikan ternak, sehingga seringkali petani peternak memberikan begitu saja rumput atau jerami yang diperolehnya. Padahal kalau dilakukan pencacahan rumput sebelum diberikan ternak, akan meningkatkan daya cerna sehingga menambah nilai kemanfaatan bagi ternak. Solusi yang ditawarkan adalah dilakukan pendidikan dan penyuluhan pengolahan limbah kotoran ternak menjadi kompos, upaya pemanfaatan jerami padi dan jagung dengan teknologi fermentasi, dan upaya perbaikan pemberian pakan sapi dengan alat pencacah rumput.
\end{abstract}

Kata Kunci: Kompos, Jerami padi fermentasi

Received 1February 2018 | Revised 30 March 2019| Accepted 3 April 2019

\footnotetext{
*Corresponding author at: Diponegoro University, Tembalang Campus, Semarang, Central Java, Indonesia

E-mail address: eny_fuskhah@yahoo.com
} 


\section{Introduction}

Mranggen Subdistrict is a sub-district in Demak Regency, Central Java which consists of 19 villages with an area of $72.22 \mathrm{~km} 2$. The population per April 2010 was 157,515 people, the density reached 2,181.44 people / $\mathrm{km} 2$. Mranggen Subdistrict is the most populated sub-district and the highest economic level among other sub-districts in Demak Regency. Sumberejo Village is one of the villages in Mranggen sub-district which has an area of \pm 888.9 ha and geographically is at 110.51615 Longitude Coordinates and -7.090886 Latitude Coordinates. While Mranggen District is at $7^{\circ} 1$ ' 41 "North Latitude and $110^{\circ} 30^{\prime} 55^{\prime}$ East Longitude, then Demak Regency is at 6 53' 27 "South Latitude, and $110^{\circ} 38$ '23" East Longitude. Sumberejo Village is a rainfed agricultural area, because it does not have access from rivers or dams [1].

In recent years, Mranggen sub-district has shown a very prominent development. The variation in the economic activities of the population is growing very significantly. At present, Mranggen District has public market facilities that are very dominant in coloring almost all activities around it. The existence of the trade facilities on the Semarang Purwodadi highway is a trigger for the growth of various activities, economic and social facilities. Almost all trade, service and social facilities are growing rapidly here, starting from trade / economic facilities, services, education, transportation, settlements and so on. This rapid development seems to be largely influenced by its proximity to the City of Semarang. The acceleration of the growth of the built area was also triggered by the existence of several existing factories and / industries.

Sumberejo is one of the villages in Mranggen sub-district which is quite densely populated. The close proximity of Mranggen sub-district, especially Sumberejo village to Semarang city, has caused people's lives to blend with the lives of the people of Semarang city. This can be seen clearly the high mobility of the residents of Sumberejo village to the city of Semarang. The heavy traffic flow on the road segments that connect Sumberejo village with Semarang city in the hours before or after school and home office, shows the number of activities of Sumberejo village residents to the city of Semarang [1].

Another problem that arises is that many villagers prefer to become factory workers rather than processing land / rice fields. The agricultural sector is considered less promising and less attractive to some residents. Many problems are faced by farmers in Sumberejo village. Farmers in Sumberejo village mostly grow rice and corn. Some of them also raise cows. They belong to several Farmer Groups. The Farmers Group, which 
has quite a lot of members, are the Farmers Group Dadi Rahayu and Dadi Rejo. The Dadi Rahayu farmer group consists of 20 people with 40 cows, and the Dadi Rejo farmer group consists of 21 people with 25 cows.

Some of the obstacles faced by cattle farmers were the problem of food availability, especially in the dry season. In this season, many farmers were looking for grass until they leave the village due to food difficulties. While at harvest, the availability of straw was very abundant. Therefore, preservation efforts were needed as well as processing straw for animal feed as a supply during the dry season.

Rice straw and corn are plant wastes that are very potential as fiber source feed. Rice straw and corn contain a relatively high amount of protein, fat, and starch and crude fiber due to high lignin and silica. The quality of straw can be improved both chemically and biologically. Improving the quality of straw in biology is through fermentation. Fermentation is the process of breaking organic compounds into simple ones involving microorganisms in order to produce a product that has a nutrient content, a texture that better extends the storage period, controls the growth of microbial contaminants.

To prepare straw as animal feed, it needs to be treated biologically by using fermentation technology Fermentation technology requires a fermentation starter containing cellulolytic microorganisms. Starter fermentation is a mixture of various microorganisms that are useful for accelerating the process of breaking fiber in straw, so that it is easily digested by livestock.

The large amount of cow dung around the enclosure also raises our concerns together. In addition to causing environmental sanitation problems, livestock manure can actually be used for various purposes such as biogas and compost products. Compost is the result of fermentation or decomposition of organic materials such as plants, animals, or other organic waste [2]. The addition of organic matter to the soil is expected to improve the quality of soil physics, improve nutrient availability in the soil, improve the ability of soil to hold water available and be able to improve plant growth [3]. Organic material in the form of organic fertilizer can function as a buffer (buffer) and soil moisture retaining. The quality of organic fertilizer is determined by the composition of the raw material and the level of decomposition [4].

\section{Method}


Based on surveys, observations, and data collection on various problems faced by partners, an alternative solution was sought. The solutions offered were:

1. Education and counseling about processing livestock manure into compost,

2. Education and counseling efforts to utilize rice and corn straw with fermentation technology,

3. Efforts to improve cattle feed by using grass chopping tools,

4. Demonstration and guiding the use of grass chopper tools.

\section{Partner Contributions}

Partner contributions to the Community Partnership Program activities were:

1. The partner provided a place / location for the Community Partnership Program activities, and invited the target farmer group members to be trained. The Community Service Team provided the human, technological, and tools needed.

2. Partners provided samples of rice straw and corn for straw fermentation practice materials and materials for practicing grass / straw counting with machines.

\section{Evaluation Design}

The evaluation applied was divided into 3 stages:

1. Initial evaluation in the form of a pretest conducted before the activity take place to determine the participants' initial abilities.

2. Process evaluation was carried out by looking at the presence and sincerity of the participants following the education and training on technology that will be introduced.

3. The final evaluation was in the form of a post test to determine the improvement in the knowledge, abilities, and skills of the trainees. Also carried out an evaluation of the interest of participants to follow up on the activities that have been carried out.

\section{Result and Discussion}

a. Initial conditions

The initial step of the activity was to coordinate between the team, field extension officers and the head of the Farmer Group Dadi Rahayu and the head of the Dadi Rejo Farmer Group, both of which were in Sumberejo Village, Mranggen District, Demak Regency as partners in the Community Partnership Program (PKM). Coordination was carried out, among others, with the aim of disseminating the intended PKM activities to the chairperson and all members of the target Farmer Group.

Other activities that have been carried out are the preparation of counseling materials, purchasing materials for the practice of making compost and fermented rice / corn 
straw, ordering and purchasing grass / straw chopping equipment. The existence of a grass / straw counter tool greatly helps the two target farmer groups to increase the digestibility of the grass / straw, so that it can improve the efficiency of the given hay / grass feed.

Extension material about composting and fermented rice straw was prepared. Before counseling, pre-test was carried out with compost and fermented rice straw material to find out how far the participants' knowledge was, namely the members of the target farmer group about compost and fermented rice straw. The results of the pre-test showed that knowledge was still very low from the members of the farmer groups about the two things. For Dadi Rahayu farmer groups, only $13.3 \%$ of the members were able to answer the questions correctly $70 \%$ of the questions, $20 \%$ of the members were only able to answer $10 \%$ of the questions. While the farmer group Dadi Rejo, as many as $23 \%$ of members were able to answer $90 \%$ of the questions correctly, there were even $30.8 \%$ members who were only able to answer $10 \%$ of the questions given.

b. Processing of livestock manure into compost.

Composting with Stardec activator

The use of activators was a way of making compost quickly and can be done aerobically. Making organic fertilizer cannot be separated from the composting process caused by microbes that act as decomposers or decomposition of various organic wastes that are used as compost-making materials. The use of microbes as an activator to obtain compost with good quality depends on the ingredients used, how to make it, the place of manufacture and the length of composting.

One of the frequently used activators or decomposers was Stardec or Starbio. Stardec activator contains several microbes that play a role in decomposition of organic waste to become compost. These microbes were lignolytic, cellulolytic, proteolytic, lipolytic, aminolytic and microbial non-symbiotic nitrogen fixation.

Material needed in making 1 ton of compost:

- 1 ton of organic material (rice straw / manure / other agricultural waste which available at the location)

- $\quad 2.5 \mathrm{~kg}$ stardec

- $100 \mathrm{~kg}$ of sawdust (can be replaced with bran or other fine ingredients)

- $100 \mathrm{~kg}$ of ash and $20 \mathrm{~kg}$ of calcite or dolomite.

The application of stardec microbial fertilize is as follows :

1. Prepare compost processing media in a protected place or not subject to direct sun, can be under the roof of a cottage or under a tree with a base or floor made rather 
high to avoid standing water. Compost processing could also use hole-shaped media with a size within $1 \mathrm{~m}$, width $2 \mathrm{~m}$ to $3 \mathrm{~m}$ and length depending on location and needs. We recommend that you build a special building for continuous processing.

2. Mix organic matter (manure or other agricultural waste) with sawdust, ash and calcite then stir evenly

3. Make a layer as high as $60 \mathrm{~cm}$ sprinkle Stardec evenly on the basic ingredients of compost, then coated again as high as $60 \mathrm{~cm}$ and sprinkle Stardec back evenly. And so it was calculated according to the capacity of the material being processed

4. During the composting process, add water to the organic material to maintain the moisture content and the humidity remains around $50-60 \%$

5. The stack of material was reversed once a week with the composting process for 3-4 weeks. If you want to speed up the composting time, urea fertilizer could be added as much as $2.5 \mathrm{~kg}$ per ton of organic matter.

6. Characteristics of mature compost, namely the color becomes blackish brown, changes in shape into crumbs, did not smell, the temperature was not hot.

Mature compost characteristics:

1. The color becomes blackish brown,

2. Changes form into crumbs,

3. No smell and no heat.

Using compost

Compost was given to the land by giving it to the path or land that was hoeed or around the planting hole before planting. For lowland rice plantations, a minimum of 2 tons of compost was used and corn plants were 2-4 tons of compost. The use of compost could be combined with $50 \%$ used of chemical fertilizer recommendations.

The use of compost had begun to develop at the farm level, not only for rice and secondary crops, but also for vegetables. The dosage of compost in vegetable plants (chili, tomato and others) ranges from 10-20 tons / ha or 0.5 to $1 \mathrm{~kg}$ of compost / plants. With the use of 0.5 to $1 \mathrm{~kg}$ of compost / plants, chili fruit stems tend to be stronger so that they could reduce flower fall. In eggplant plants, making compost caused eggplant fruit to become large.

The benefits of using compost were processed with the addition of stardec or starbio, which were: increasing soil microbes, improving soil physical and chemical properties, increasing water retention so as to maintain and increase soil moisture, provide micro elements needed by plants even in small amounts, and improve fertilizer efficiency 
(reduce the use of chemical fertilizers by 30-50\%), reduce the cost of using fertilizers and increase production. With the used of at least 2 tons of stardec compost, the used of chemical fertilizers (urea, SP-36 and $\mathrm{KCl}$ ) could be reduced by up to $50 \%$. Production of plants with full chemical fertilizer used (100\%), was no different from the production of plants with the use of $50 \%$ chemical fertilizer plus compost 2 tons / ha. Thus, the capital of farmers to buy chemical fertilizers could be suppressed. In the long run, it was expected that production would increase because land would become more fertile.

c. Fermentation of Rice Straw and Corn

Materials that need to be needed:

- Rice straw or maize that had dried as much as 1 ton,

- Starter fermentation 1 sample bottle of commercial starter: EM 4, Starbio, Liquid Organic Supplement / SOC, etc.),

- Molasses (sugar cane drops), if there was no molasses could be replaced with sugar as much as $1 \mathrm{~kg}$,

- Enough water,

- Sheet or sheet plastic,

- Plastic buckets,

- Shepherd or water sprinkler.

How to make fermented straw feed :

- Prepare a place that was protected from rain, stagnant water or direct sunlight,

- If the base of the floor was still from the ground, please provided a plastic mat or a strong tarpaulin so that the water from the fermentation mixture did not seep into the soil,

- Prepare dried straw, if the straw was still wet, please dry it in the sun in the sun first,

- Take a bucket, fill the water then pour the fermented starter and molasses into the bucket, stirring until smooth,

- Begin laying the first layer of straw 15-20 cm high and start spraying the solution of water mixture, starter fermentation, molasses in the haystack and trampled, try to spray evenly and the straw looked wet,

- After all the straw had finished, close the haystack with tarps or plastic,

- Tie the meeting and try not to get air in, let the haystack stand for 12-15 days so that the fiber decomposition process in the straw runs naturally. This fermentation process did take a few moments so that the straw was completely weathered and the nutrients were added. This will greatly aid digestion in absorbing this fermented nutrition, 
- After 12-15 days, fermented straw was ready to be given for animal feed, which was previously aerated first,

- Improved conditions for PKM activity partners could be seen in Table 1.

Table 1. Partner conditions before and after PKM activities

\begin{tabular}{lll}
\hline No & Partner Conditions Before PKM & Partner Conditions After PKM \\
\hline 1. & Providing cattle feed in the form of & Cattle feed was more varied in the form of \\
& rice straw, grass and cassava & fermented rice straw, grass and \\
& & $\begin{array}{l}\text { concentrates in the form of a mixture of } \\
\text { tofu dregs, bran and chopped cassava as } \\
\text { feed for cattle }\end{array}$
\end{tabular}

2. Crude Protein Content $(\mathrm{PK})$ of rice Increased crude protein content of straw straw before fermentation $3.5 \%$ becomes $7 \%$ or increases by 2 times

3. Total Digestible Nutrient content of Total Digestible Nutrient (TDN) content $=$ rice straw $(\mathrm{TDN})=30 \% \quad 30 \%$ to $70.1 \%$ or increase by 2.3 times

4 Digestion of rice straw was low, only Digestion of fermented rice straw $28-30 \%$ increased to $50-60 \%$ or increased by 2 times

5. Cattle weight gain which consumed Cattle weight gain which consumed 120 days of rice straw increased from fermented rice straw was maintained for $250 \mathrm{~kg}$ to $288 \mathrm{~kg}$, weight gain of $38 \mathrm{~kg} 120$ days, increasing from $250 \mathrm{~kg}$ to 327 or daily weight gain of $0.32 \mathrm{~kg} /$ day $\mathrm{kg}$, increasing by $77 \mathrm{~kg}$ or daily body weight gain of $0.64 \mathrm{~kg} /$ day

6. There was no income from compost Income from compost

Materials:

$1000 \mathrm{~kg}$ cow manure

Stardec $2.5 \operatorname{kgx} 14,000=35,000$

Bran $100 \mathrm{~kg} \times 3750=375,000$

Ash $100 \mathrm{~kg} \times 2000=200,000$

Dolomite $20 \mathrm{kgx} 8500=170,000$

Total $=780,000$

The total material is $1222.5 \mathrm{~kg}$ of shrinkage of $20 \%$ so that the total compost $=978 \mathrm{~kg}$

Cost $/ \mathrm{kg}=780,000 / 978=\mathrm{Rp} .797,-$

Selling price $/ \mathrm{kg}=\mathrm{Rp} .1500,-$

Profit $=1500-797=$ Rp. $703,-/ \mathrm{kg}$

Weight of cow manure $20 \mathrm{~kg} /$ day $=20 \mathrm{x}$ 703

Profit $=$ Rp. 14,000 / cow / day 


\section{d. Grass/Straw Chopper}

As an effort to improve cow feeding, each partner was given 1 grass / straw chopper.

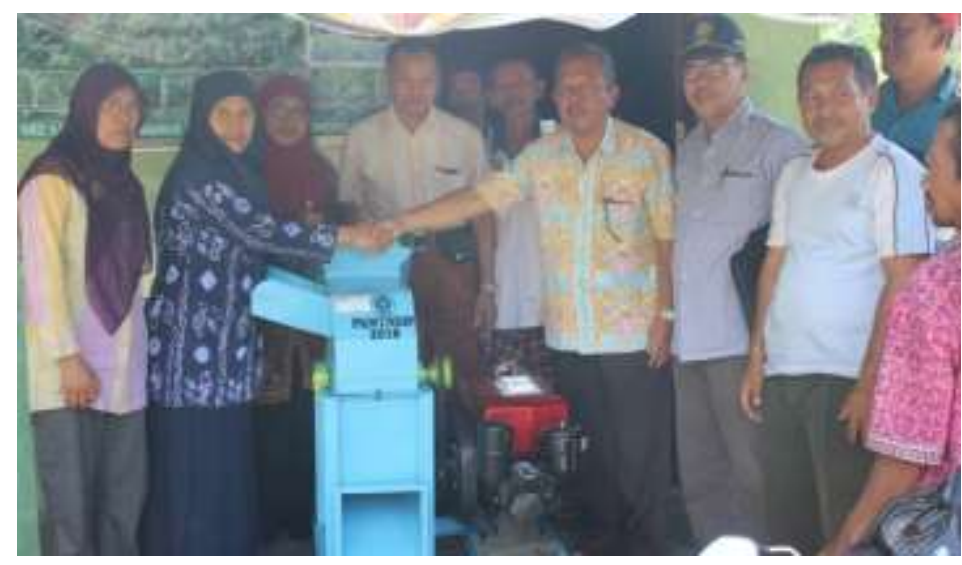

Figure 1. Handover of grass chopper to Sumberejo village head witnessed by chairman and members of farmer groups and field extension officers in Mranggen sub-district

e. Final Evaluation

The final evaluation of all activities was carried out by post test to find out the increase in knowledge, insights and skills of participants. After counseling, a post test was given to determine the increase in knowledge of the trainees with the same questions as the pre test questions. The results of the post test obtained were very encouraging, even though none of them succeeded in answering the question $100 \%$ correctly. Members of the Dadi Rahayu farmer group, $93.3 \%$ were able to answer $90 \%$ of the questions correctly, and the remaining $6.7 \%$ were able to answer $80 \%$ of the questions correctly. Members of the Dadi Rejo farmer group were able to answer $90 \%$ of the questions correctly as many as $84.6 \%$ of the members, and the remaining $15.4 \%$ of the members were able to answer $80 \%$ of the questions.

Evaluation was also conducted to see the interest of the participants in following up on the activities that had been carried out. It is hoped that the farmers would easily adopt the knowledge and be able to truly utilize the knowledge that has been obtained so that additional income will be obtained from the sale of compost, or the use of compost for each plant, thereby reducing the cost of purchasing chemical fertilizers. Thus, in addition to increasing income, it also reduces environmental pollution due to the accumulation of livestock manure around the enclosure. Rice straw technology was also very helpful in providing food in the dry season while increasing the nutritional value of straw. The hope was that there will be a significant increase in production and income. 


\section{Conclusion}

The conclusion that could be drawn from the Community Partnership Program (PKM) activity of Sumberejo Village Farmers Group, Mranggen Subdistrict, Demak Regency, Central Java Province, was very important to know the problems faced by target farmer groups so that they can provide appropriate problem solving methods to increase income and environmental management. Thus, farmers could obtain multiple benefits which ultimately could improve their standard of living. Suggestions that could be conveyed were necessary guidance and assistance that were serious enough so that farmers were able to adopt the knowledge provided well.

\section{References}

[1] BPS. Mranggen Subdistrict in Number. 2008. BPS Jakarta.

[2] Indriani, Y.H. Make Compost Quickly. 2012. Penebar Swadaya. Jakarta.

[3] Zulkarnain, M; B. Prasetya; Soemarno. The Effect of Compost, Organic fertiliser and Custom-Bio on land properties, growth and sugarcane yield (Saccharum officinarum L.) at Entisol at Ngrangkah-Pawon garden, Kediri). 2013. Indonesian Green Technology Journal. Vol. 2 No. $1:$ 45-52.

[4] Nuraini, Y dan Nanag Setya Adi. The Effect of organic fertiliser and organic matter on chemistry, biology properties of land and production increase of Zea Mays L. 2003. Habitat. Vol XIV No 3 : 139-145. 